\title{
The Language Socialization and Identity Negotiations of Generation 1.5 Korean- Canadian University Students
}

\author{
Jean Kim and Patricia A. Duff
}

This article, based on a larger longitudinal multiple-case study of Generation 1.5 Korean-Canadians, explores two female students' experiences in high school and then university. Foregrounding aspects of language socialization (Duff E Hornberger, 2008) and identity (Norton, 2000) in language-learning and use, the study examines the contextual factors involved in the students' language socialization in and through Korean and English. The findings reveal that through the complex interplay of their past, present, and future "imagined" experiences, the students were socialized into various beliefs and ideologies about language-learning and use, often necessitating the negotiation of investments in their identities in relation to Korean and English. Given the personal backgrounds of these students, coupled with the phenomena of globalization and transnationalism, we suggest that Canadian universities and Generation 1.5 students and their families pay more attention to the students' linguistic, educational, and social backgrounds, affiliations, and trajectories by underscoring the advantages of bilingualism and biculturalism along with the importance of English for integration into Canadian society and international networks.

Reposant sur une plus grande étude longitudinale de cas multiples qui porte sur la génération 1.5 de Canadiens coréens, cet article vise les expériences de deux étudiantes au secondaire et ensuite à l'université. Mettant au premier plan des aspects de la socialisation linguistique (Duff E Hornberger, 2008) et de l'identité (Norton, 2000) dans le contexte de l'apprentissage et de l'usage de la langue, cette étude examine les facteurs contextuels qui touchent la socialisation linguistique des étudiants en coréen et en anglais, ainsi que par le biais de ces deux langues. Les résultats indiquent que par une interaction complexe des expériences antérieures, présentes et telles qu'imaginées à l'avenir, les étudiants étaient socialisés vers diverses croyances et idéologies relatives à l'apprentissage et l'usage de la langue; ce processus impliquait souvent des négociations de leur identité par rapport au coréen et à l'anglais. Compte tenu des antécédents personnels de ces étudiantes dans le contexte de la mondialisation et du transnationalisme, nous proposons que les universités canadiennes et les étudiants de la génération 1,5 et leur famille portent plus attention aux vécus, affiliations et trajectoires linguistiques, éducationnels et sociaux des étudiants et ce, en soulignant les bienfaits du bilinguisme et du biculturalisme, et l'importance de l'anglais pour l'intégration dans la société canadienne et les réseaux internationaux. 
The increasing number of Generation 1.5 immigrant youth, namely, foreignborn children who immigrated to their host country with their first-generation parents (Rumbaut \& Ima, 1988), has changed the demographics in North American schools. Since the 1990s, there has been a steady increase in the number of child immigrants, and $21 \%$ of the 1.1 million who immigrated between 2001 and 2006 were school-aged children aged 14 and under (Statistics Canada, 2008). As a result, those who speak English as a second language (ESL) constitute a considerable and growing proportion of the student body in secondary schools across major urban cities, including Calgary, Toronto, and Vancouver (Watt \& Roessingh, 2001), much as they do in the United States (Fix \& Passel, 2003).

Many immigrant ESL students in Canadian secondary schools subsequently enter Canadian postsecondary institutions. However, much of the immigrant education research reviewed below has focused on K-12 students, and studies on immigrant ESL students at the tertiary level have mostly examined writing or composition program contexts in the US. Consequently, little is known about the language-learning experiences and goals of Generation 1.5 university students in general or in mainstream content courses in Canadian universities.

In this article, we examine the reported language socialization of Generation 1.5 Korean university students in a university in western Canada. By exploring the experiences recounted by two female students, this study yields insights into some of the contextual factors, tensions, ambivalence, and indeterminacy that affect English-language learning and use of contemporary Generation 1.5 Korean-Canadian university students.

\section{Theoretical Framework}

According to Ochs and Schieffelin (2008), learners are socialized both into and through language by means of interactions with others. These interactions, they explain, constitute

socially and culturally grounded enactments of preferred and expected sentiments, aesthetics, moralities, ideas, orientations to attend to and engage people and objects, activities, roles, and paths to knowledge and maturity as broadly conceived and evaluated by families and other institutions within a community. (Heath, 1983, p. 5)

Again citing Heath's seminal work, they assert that "the social, emotional, and intellectual trajectories of children and other novices are complexly structured by webs of social and economic institutions, public and domestic systems of control, practices, identities, settings, beliefs, meanings, and other forces" (p. 8). Therefore, examining these webs and forces is foundational to understand newcomers' trajectories as learners and members of new communities and cultures as a result of language socialization (LS). 
Early studies on L1 socialization in various contexts around the world (Ochs, 1988; Schieffelin, 1990; Watson-Gegeo, 1992) demonstrated how newcomers or novices would be socialized by expert members in the target-language community such as parents or older siblings and would internalize the new social and linguistic practices accordingly. Increasingly, however, LS research has begun to examine dynamic bilingual and multilingual communities of learners, including adolescents and adults, who are affected by processes of globalization and transnationalism (Duff, 2010a, 2011; Duff \& Hornberger, 2008; Duff \& Talmy, 2011; Duranti, Ochs, \& Schieffelin, 2011; Guadardo, 2009; Li, 2000; Schecter \& Bayley, 2002).

One related and particularly fertile area for research has been the academic acculturation, socialization, and coping strategies of immigrant and international students in secondary schools and universities (Cheng \& Fox, 2008; Duff, 2008a, 2010b; Duff \& Kobayashi, 2010; Fox, 2005; Morita, 2000, 2004; Morita \& Kobayashi, 2008; Séror, 2008; Yim, 2011; Zappa, 2007; ZappaHollman, 2007). Harklau (2003), for example, examined how the socialization practices in a secondary school in the US created a representation of immigrant students as motivated and hardworking, but nonetheless cognitively and linguistically deficient. Talmy $(2005,2008)$ looked at Generation 1.5 high school students in Hawaii and the cultural production of ESL in everyday classroom practices that positioned learners in disadvantageous and often contradictory ways. Moreover, Duff's $(2001,2002,2004)$ studies on the experiences of Asian ESL students in secondary school social studies classrooms in Canada revealed that in addition to linguistic difficulties, the students faced challenges due to their lack of knowledge of contemporary North American vernacular English, pop culture, and current affairs, and their perceived social exclusion or indifference on the part of local peers. Thus these studies illustrate the complex interactions among social, linguistic, academic, and cultural factors in newcomers' socialization and integration in their new second-language (L2) academic communities.

Social identity is another important aspect of language learning, use, and socialization (Block, 2007). Norton (2000) defines identity as "how people understand their relationship to the world, how that relationship is constructed across time and space, and how people understand their possibilities for the future" (p. 5). Further, Norton emphasizes the concept of investment in language-learning and identity in her study of immigrant women in Canada. Drawing on Bourdieu's (1977) notion of cultural capital, she argues,

If learners invest in a second language, they do so with the understanding that they will acquire a wider range of symbolic and material resources, which will in turn increase the value of their cultural capital. (p. 17) 
Thus Norton claims that when individuals invest in a target language, it is also an investment in their social identity, which continually changes over time and space. McKay and Wong's (1996) study also highlighted Chinese-American immigrant high school students' L2 learning experiences and varying investments in English as they negotiated multiple identities and exercised their agency in the many discourses and counter-discourses surrounding them.

\section{Research on Generation 1.5 Youth}

Early works on Generation 1.5 students stemmed from the fields of sociology and immigrant studies, which often portrayed this group as being lost and caught between two worlds (Roberge, 2009). Sociologists Rumbaut and Ima (1988), who first coined the term Generation 1.5 to describe the Southeast Asian refugee youths involved in their study, depicted the youth as "marginal to both the new and old worlds, for while they straddle both worlds they are in some profound sense fully part of neither of them" (p. 22). In illustrating the experiences of Generation 1.5 Korean-American youth, Ryu (1991) characterized them as marginalized, pessimistically claiming that "the 1.5 generation can be forever lost, and most of them are lost" (p. 51). More recently, however, scholars have cautioned against an essentialized view of immigrant youths' identities, including those of Generation 1.5 students, arguing that identity is dynamic and multidimensional, influenced by social environments, sociopolitical interests, transnational experiences, and discourse itself (Block, 2007; Jo, 2002; Kibria, 2000; Lien, Conway, \& Wong, 2003; G.C. Park, 2001; Roberge, 2002; Talmy, 2005). Moreover, rather than employing simplistic ethnic labels, some scholars have adopted notions of hybridity or third spaces (Bhabha, 1990; Kramsch, 1998; Zentella, 1997) to describe immigrant youths' and other transnationals' identities. The processes and outcomes of socialization into various identities/spaces, practices, and communities, however, require additional research.

Until the 1990s, ESL research in higher education almost exclusively involved international students (Crisostomo \& Dee, 2001; Harklau, Losey, \& Siegal, 1999). Then, from the mid-1990s, a growing number of studies situated in the US mainly addressed how existing pedagogical and educational structures and policies, especially those of college ESL and composition/writing programs, failed to cater to the unique characteristics and needs of Generation 1.5 students (Blumenthal, 2002; Harklau, 2000; Harklau et al.; Leki, 1999; Miele, 2003; Oudenhoven, 2006; Roberge, 2001; Roberge, Harklau, \& Siegal, 2009; Schwartz, 2004; Singhal, 2004; Stegemoller, 2004; Talmy, 2005; Yi, 2009).

Although such studies offer valuable insights, there is a need to extend the discussion of Generation 1.5 issues beyond high school, college, and university English writing or remedial courses to the broader historical, sociocultural, and political framework surrounding the students' experiences in other venues, thereby yielding a more in-depth and nuanced understanding 
of their language learning and use, socialization, and positioning. Also, whereas many studies have looked at ESL immigrant students' educational experiences in Canada (Duff, 2001; Gunderson, 2007; Roessingh \& Kover, 2002; Toohey, 1992, 2005; Toohey \& Derwing, 2006; Toohey \& Gajdamaschko, 2005), more studies on Generation 1.5 students in Canadian higher-educational contexts would help educators understand their past and present experiences and their long-term trajectories. This study was undertaken to examine the experiences of Generation 1.5 Korean-Canadian university students, but not with primary reference to English-writing instruction.

\section{Why the Korean-Canadian Community?}

Ilch mo-se, literally Generation 1.5 in Korean, has been a commonly used term in both the native Korean and Korean-American media for the last few decades, and it has spread to other Korean immigrant communities including those in Canada (Kim, 2008). The term was first used in the Korean-American community in the 1970s to describe immigrants who arrived in the US as children (Danico, 2004; Hurh, 1993; Roberge, 2002).

However, despite the widespread use of the term Generation 1.5 among Korean immigrants in North America, not enough is known about this population (Danico, 2004). Moreover, as Yoon, Lim, and Bae (2007) assert, compared with the existing research on Generation 1.5 Korean-Americans (Danico; Jeon, 2001; Park, 1999; Yi, 2009), there are few studies on Generation 1.5 Korean-Canadians. A small number of studies have examined issues related to Korean visa or international students of various ages in Canada though, broaching similar issues, especially related to the pressure to cultivate and perform identities as cosmopolitan, "cool," Korean-pop-culture-literate youth with strong alliances in local Korean peer networks where displays of Korean identity are crucial (Duff, 2007; Shin, 2010).

Koreans represent one of the most rapidly growing immigrant groups in Canada, and 35\% of those who immigrated between 1996 and 2000 were in the 5-19 age group. Thus Generation 1.5 youth are a considerable constituency in the overall Korean immigrant population in Canada (Statistics Canada, 2008). Furthermore, many Korean immigrant youth now study in Canadian universities because the primary reason for Koreans' emigration is for their children's educational achievement (Moon, 2003; Yoon, 2001). Therefore, Korean-Canadian youth represent an important population to examine in LS research on Generation 1.5 students in Canada.

\section{The Study}

The study addresses the following two research questions:

1. What are the contextual factors that shape the language socialization processes and outcomes of Generation 1.5 Korean-Canadian university students as exemplified by two case study participants? 
2. How do such contextual factors influence the students' investments in their identities and (Korean and English) language learning and use? How are these investments manifested in their everyday lives?

The study focuses on the experiences of two female Generation 1.5 KoreanCanadian university students, Yellina and Sheila (pseudonyms). Both women were participants in a larger longitudinal multiple-case study (Kim, 2008) with seven Generation 1.5 Korean-Canadian students, a mixture of men and women, who attended Pacific Canadian University (PCU, a pseudonym). PCU is a large research-intensive university located in Metropolitan Vancouver, a city with a nearly $40 \%$ foreign-born population (Statistics Canada, 2008). Since 2001, Asians and Middle Easterners comprise most of Vancouver's immigrant population, with Koreans as its fourth largest non-European immigrant community.

Once we received ethics approval from the university, we recruited participants through Korean student networks and organizations at PCU. Students who consented to participate took part in monthly individual semistructured interviews with the first author (see Appendix A for sample interview questions). Other data included information obtained from a background questionnaire, the researcher's field notes and reflection journal, interviews with first-year English course instructors at PCU, as well as students' personal writings and other forms of individual correspondence such as e-mail and Web messenger. Last, Kim held informal personal meetings with participants. The aim was to increase the trustworthiness of data and analysis by using multiple data sources, methods, and theoretical lenses, also known as triangulation (Duff, 2008b; Marshall \& Rossman, 1989).

Interviews took place on campus from September 2005 to June 2006 and lasted 50-60 minutes each, with some additional communication during and after the academic year had ended with participants' permission. The participants and the interviewer, Kim, are bilingual in Korean and English, so interviews were conducted in Korean, English, and a mixture of both. All interviews were audio-recorded and transcribed, and summaries were crosschecked with the students either at the beginning of the next meeting or by e-mail or Web messenger exchanges. Students were asked to read the transcripts, which were translated into English, to ensure that their original meanings were accurate.

The experiences or beliefs presented in the analysis are thus based to a large degree on participants' selective narrative (re)constructions and sense-making of their lives as bilingual Korean-Canadians as recounted to the Korean interviewer and should be interpreted as such. Moreover, although we attempted to represent the students' voices as much as possible, the interface between interviewer and interviewee inevitably affects the dynamics of the interviews as well as how participants' accounts are (co)produced and interpreted (Talmy, 2010). Kim's shared cultural and linguistic 
background with the students afforded her insider status in some ways. However, in other respects, she was an outsider because of her non-immigrant status (but one who had herself lived in Canada as a high school student), her educational background and current status, and age (at least 10 years older). Thus the interviewer was continually renegotiating her identities as an insider, an outsider, and a bilingual transnational Korean during her interactions with the students.

We analyzed the data throughout the entire data-collection process so as to identify the recurrent themes and patterns that surfaced within and across cases. From the complete dataset of seven Korean-Canadian participants (Kim, 2008), Yellina and Sheila were selected for analysis in this article because they represented an interesting pair in terms of their academic, social, and linguistic trajectories and LS dilemmas as Korean-Canadians. Both had dreams of becoming English professors, a goal that one continued to pursue but that the other had abandoned. In addition, both cultivated strong connections with Korean-speaking peers in Canada and abroad, unlike some of their peers (Kim), who made greater efforts to align themselves with English and English-speaking peers. Examining their perspectives, therefore, illuminates the choices, ambivalence, and misgivings of some students with respect to their English-language learning, use, and identities in Canada.

Profiles of Yellina and Sheila are presented in the following section. Their trajectories are traced based on their retrospective and prospective accounts, as English-language learners, as students, and as bilinguals from the time of their arrival in Canada. In this way, we examine the interplay between the various contextual factors in their past, present, and (imagined) future contexts, which contributed to the complexity of their language socialization process, particularly with respect to English.

\section{Yellina}

In 1999, when Yellina was 15, she immigrated with her parents and younger brother to Vancouver. Her father had been a small-business owner in Seoul, and her mother had been a dance teacher. The failure of her father's business was the reason for seeking a fresh start in Canada, where opportunity and quality education were available. Initially, Yellina was resistant to moving to another country. Based on the images she saw of Korean university life in televised dramas and movies, she was determined to attend university in Korea. Thus when her parents announced their move to Canada, she felt that her future plans were being derailed without her consent.

Once in Vancouver, Yellina's parents opened a small restaurant without much success. Her father returned to Korea to restart a business and became what is known as a kir gi or "wild goose," a non-resident, offshore father (Yoon, 2001), traveling between Korea and Canada for about six years while the rest of the family remained in Vancouver. When her younger brother en- 
tered PCU in 2005, her parents prepared for reverse migration (Hurh, 1998; Yoon) and eventually returned to Korea permanently in early 2007.

\section{Sheila}

In 2000, when Sheila was also 15 years old, she immigrated to Canada with her parents and older sister. The family believed that Canada would provide a less stressful work environment for the father, a research scientist in Korea, as well as quality education for the children. They chose Calgary in the hope that the children would acquire English quickly in a city with few Korean immigrants. In 2004, when Sheila was accepted at PCU, her parents closed their business in Calgary and moved to Vancouver with her and her sister, who transferred to PCU from a university in Calgary.

At the time of the study, her parents ran a motel on Vancouver Island while Sheila and her sister lived in Vancouver. Sheila traveled four hours almost every weekend to help with her parents' business. Although the parents' English was good enough to run the business, they still relied on their children for matters requiring more sophisticated English skills. Sheila's parents, like Yellina's, were hoping to return to Korea once Sheila was settled professionally in Canada. Her sister, also determined to return to Korea for work on graduating from PCU, had been unable to do so by the end of this study.

\section{Experiences in High School}

\section{Yellina: Korean Peer Influence on Linguistic, Academic, and Social Choices}

Yellina enrolled in a multicultural secondary school in Vancouver, which included a fairly large Korean population. In her grade alone were 20-30 Korean students, many of whom were recent immigrants like her. As mentioned above, Yellina was initially unhappy with her family's move to Canada; thus when she first transferred to her new school, she had no desire to make Canadian friends. Instead, she socialized with other Korean students. However, one of the most crucial factors in being able to maintain her affiliation with this group was to speak with them only in Korean. According to Yellina, there was a strong dislike of Korean students who spoke English in the presence of other Koreans, which polarized the immigrant group.

I have this thing about Koreans speaking English with each other. From the beginning, I hated Koreans who spoke English to other Koreans if I knew they spoke Korean fluently. In high school, there were these two different groups. One group hung out with only non-Koreans and avoided Koreans completely and the other group hung out with both non-Koreans and Koreans. My friends and I were always speaking badly about the first group. It was obvious they were using English because they didn't want to be close to Koreans. 
So speaking English was perceived as an act of betrayal or lack of allegiance to one's Koreanness. Yellina's comments reflect the findings of Palmer's (2007) study of ethnic Korean students in a US high school, where authentic Korean identity was questioned based on the language students chose to speak with one another. The Chinese-Canadian high school students in Pon, Goldstein, and Schecter's (2003) also reported feeling caught between loyalties toward their Chinese peers, who discouraged the use of English, and their desire to use English more to obtain good grades.

In addition to speaking Korean, having knowledge about the latest news in Korean popular culture was important. Still deeply immersed in Korean culture, returning to Korea for university was a hot topic discussed among Yellina's peers. Without her father's strong opposition, Yellina would have returned to Korea for university. Hence she spent most of her high school years feeling indifferent toward the language and culture of her new home.

Yet in one context she was determined to excel: ESL classes in which she was enrolled for a year during grade 9 . Yellina often spoke about wanting to escape or transition from ESL classes in high school in response to competitiveness among Korean ESL students and their parents' desire that they be mainstreamed quickly. A deficiency label may be associated with ESL classes (Salzberg, 1998; Séror, 2002; Talmy, 2005; Toohey, 1992; Zamel, 1995), and this stigma may have a negative effect on ESL students' self-perceptions (Cummins, 1996; Gunderson, 2000). As Yellina explained, "within the Korean community, the words ESL student were reminiscent of being below English literacy standards." In her view, the material used in her ESL classes, designed for NS kindergarten students, caused humiliation, anxiety, and desire to graduate as quickly as possible.

Yellina's parents limited her Korean video rentals, and when she expressed interest in returning to Korea for university, they urged her to attend PCU, an investment in a prestigious symbolic capital among local Koreans. Returning to Korea for university, on the other hand, was considered an exit strategy for those who had failed academically in their Canadian high schools (a reversal of the situation in the early 1990s when families sent their children abroad for university precisely because they were not accepted by Korean universities, E.K. Park, 2001).

\section{Sheila: A Struggle to Belong}

Unlike Yellina, Sheila was excited to move to Canada. However, she remembers her high school years as lonely and stressful. On arrival in Calgary, she enrolled in grade 9, without formal ESL instruction to non-native speakers (NNS), in a predominantly White Anglo-Canadian school. As one of the few visible minorities in the school, Sheila wanted to befriend her Canadian peers, yet was unable to do so. She reported, 
I lacked confidence in English and thought I was different from other students, so I just closed up. I didn't have anything to say when they were talking about celebrity gossip, partying, putting makeup on, and so on. So I was the one that closed the door first from them. I could've tried to create a good relationship with them, but I couldn't. I had only myself to blame. It wasn't them. I was embarrassed to approach them. It was me who did it, and since then I continue to feel intimidated when I'm interacting with White people. It's almost like I feel they might give me a signal that my English isn't good enough.

Sheila emphasizes her responsibility and shortcomings for the social isolation that she experienced, not seeing the complicity of local students. Indeed, Cervatiuc (2009) argues that often "immigrants do not have the luxury to interact with whom they choose, as their opportunities to practice English are generally limited and socially structured for them" (p. 255). Consequently, many become "marginalized, introverted, and sensitive to rejection" (p. 255). In addition, Kanno and Varghese (2010) note that "coethnic friends become a default backup for ESL college students" (p. 323) as a result of the perceived inaccessibility of friendships with NS "American" students. For Sheila, who immigrated in her teenage years in a much less multicultural context than Yellina, there were no coethnic friends at her school to turn to, so she relied on the support of her friends still in Korea (ChiangHom, 2004). Sheila coped with her loneliness through frequent e-mail exchanges and Web Messenger conversations with friends in Korea and by surfing Korean Web sites every day.

Sheila attended a more ethnically diverse high school than her previous one, and she socialized exclusively with Korean peers throughout grade 10. In addition, she immersed herself in Korean pop culture. In this circle, English use was discouraged. Unlike Yellina, however, Sheila was uncomfortable with this situation. She knew that her English was stagnating and that this situation would impede her chances of acceptance in a good university. Her strategy of mixing English and Korean while with her Korean friends was met with disapproving looks and was seen as showing off. She described feelings of being "stuck in the middle of nowhere," caught between her desire to maintain friendships and use English. Eventually, Sheila distanced herself from her Korean peers and befriended other non-Korean Asian students with whom she felt comfortable enough to use English as a lingua franca. Although some Korean friends may have perceived her as a traitor, she felt that this choice was the only one that would ensure successful graduation and entrance to university. 


\section{Experiences in University}

Yellina: "They all said I was crazy" [to major in English]

Yellina entered PCU in 2004 with the hope of majoring in English and one day becoming an English professor. Whereas Korean peers and parents influenced many of her choices in high school, she now looked to her Korean sŏnbaes or upperclassmen for "expert" advice with regard to aspects of university life, including her desire to major in English.

The sŏnbaes, they all said I was crazy and that I would never graduate if I majored in English. They said ... I should just do what everyone else does like economics or psychology. So I got really scared at that time because I thought I was making the wrong choice. So I decided to just major in Asian studies and thought it didn't really matter what I majored in.

These sŏnbaes added that because Yellina was part of the Generation 1.5 group, people whose mother tongue was other than English and whose birth and early years were in countries other than Canada, she would have to accept certain disadvantages.

Because we are so pressured and burdened by it all, we have this feeling among ourselves ... we just don't even want to look at that direction [of pursuing our dreams]. So for someone like me, we think to ourselves, English is not even our first language, how can we even dare study English literature?

Thus surrounded by sŏnbaes and peers who spoke about their fatalistic perceptions vis-à-vis their status and future potential as Generation 1.5, she gave up her dream of teaching English and planned instead to complete a degree in Asian studies.

\section{Sheila: "They told me not to try so hard" [in my studies]}

In 2004, Sheila entered PCU to major in biochemistry, then changed to immunology. She intended to attend graduate school and become a veterinarian. Initially, she avoided Korean students who might only be interested in partying and socializing. However, feeling lonely in her second year, she befriended Korean peers, which minimized the time spent expressing herself in English. She maintained excellent marks on exams, but lacked oral fluency during class discussions.

She felt anxiety when she considered working and competing with nativeEnglish speakers in Canadian society. She described feeling "pathetic" for speaking Korean with her peers. When she met a fellow Generation 1.5 Korean who spoke fluent English, she was even more self-critical. Further, when she thought about her parents' sacrifices, she was ashamed of her linguistic 
choices. On the other hand, Sheila's parents were proud of her academic success. Only Sheila considered herself a failure for lacking the discipline to speak English when such efforts were rebuffed by her Korean peers and sister.

Sometimes I try to just mix English and Korean but my sister tells me to stop because I look obnoxious, as if I think I'm behaving like I'm better than the others. We used to argue about this even in high school. She'd ask me why I am trying so hard to use English even when I'm with Koreans. She'd ask what the hell is wrong with me and told me not to try so hard.

As a result, Sheila's Korean social network, much like Yellina's, socialized her into Korean cultural and social activities and Korean-only language ideologies and interactions, and away from those in mainstream Anglophone-Canada.

\section{Negotiating Change}

Although Yellina had selected Asian studies as her major instead of English, she noted on a trip to Korea that many native non-immigrant Koreans spoke English more fluently than she did. She had believed that although her English might not be equal to that of Anglo-Canadians, it was better than that of Koreans in Korea. Now she realized that she would have to improve her English skills to compete with Koreans as well in a global market. Further, she regretted not having paid more attention to Canadian sociocultural issues while at PCU (Duff, 2001).

In summer 2006, Yellina declared English her major in order to become knowledgeable about Canadian culture and society and competitive in the global labor market. She took a proactive approach to developing her English skills. However, this new resolve was undermined by her commitment to her Korean friends. Some days she reported speaking only Korean, but she was unwilling to sacrifice her friendships for the sake of her new investment in English. Rather than minimize her use of Korean, she increased her time in English through exposure at work in a bookstore, where she had to converse in English.

Five months into this study, Sheila too was maintaining her Korean social network (Cervatiuc, 2009) and seeking opportunities to use English through work as a waitress and a volunteer at a hospital gift shop. In addition, she befriended Chinese-Canadians at PCU to practice English while having breaks or going out for coffee.

\section{Discussion}

During their LS in Canada, Korean peers not Anglophone Canadians served as Yellina's and Sheila's primary mentors and socializers, particularly with respect to gaining membership and status in coveted local Korean-Canadian 
communities of practice (Duff, 2003; Lave \& Wenger, 1991). However, these Korean peer networks, although invaluable, often precluded improvement and investment in English and in local English-speaking networks. Strong language attitudes in Korea "work against openly demonstrating one's proficiency in English" (Park, 2009, p. 35) as most Koreans view the Korean language as an essential feature of their identity. Thus opting not to speak Korean is perceived as a "disloyal act of self-denial" and an act of jalnan cheok, "pretending to be smart/good or boasting" (p. 52).

Members of their Korean peer community socialized Yellina and Sheila into sometimes contradictory ideologies regarding English-language learning and future possibilities and trajectories (Guardado, 2009) based on their views of ESL programs. In university, another kind of Korean group, namely, sŏnbaes, became the experts or the old-timer group that Yellina relied on for mentoring and from which she sought approval. Although they discouraged her from majoring in English, native Koreans still residing in Korea convinced her that improving her English skills would open opportunities for a successful future that might include transnational opportunities. Consequently, Yellina resisted the disempowering Generation 1.5 status as defined by her sŏnbaes and reclaimed her dream of majoring in English. Thus Generation 1.5 Korean-Canadians and not English NSs were Yellina's role models who mediated her linguistic, academic, and sociocultural beliefs and choices.

In Sheila's case, part of her reported frustration with her English skills was the fear that proficiency could be a disadvantage professionally when working alongside NSs of English. Still, she judged the quality of her English by Generation 1.5 Korean-Canadian standards, commensurate with five years' residence in Canada.

Moreover, certain discontinuities between home/community and school language and cultural practices were evident in both women's experiences, as well as in other cases in the larger study: high school/university; $\mathrm{ESL} /$ mainstream and conflicting language and immigrant ideologies (Baquedano-Lopez \& Kattan, 2008; Garrett \& Baquedano-Lopez, 2002; Guardado, 2009). The discontinuities in Yellina's and Sheila's experiences went well beyond differences between socialization practices across these domains. Their experiences display a disjunction between the practices required to realize their future goals either in Canada or Korea and those encouraged and supported in their immediate peer or mentor groups, unless they actively sought out other native or immigrant English-speaking communities.

Furthermore, these conflicting socialization practices mirrored the contradictory ideologies that came into play. In the boundaries of their Korean communities, consisting of peers, parents, or sŏnbaes, the women were influenced by specific beliefs of what it meant to be an ESL student, a loyal Korean, an NNS of English, and a Generation 1.5 immigrant (Korean) in Canada. These beliefs led them to make certain linguistic choices in their 
daily lives. Yet such ideologies clashed with their ideas of what it meant to be an academically successful university student, a global competitor, a dutiful daughter, and a future member of mainstream Canadian society, which eventually directed them toward (English) linguistic choices and practices that they had resisted for many years.

\section{Conclusion}

To some readers, Yellina and Sheila might represent two young, academically successful Korean-Canadian women belonging to a privileged group of new immigrants with considerable social capital and ambition. Both were living in a city that provides comfortable and easy access to Korean communities, organizations, and resources. The women also had the option to return to their economically developed native country to pursue other opportunities, as Yellina's parents had done, unlike earlier generations of Korean immigrants. These interrelated contextual and personal factors affected the reported experiences of Yellina and Sheila as well as those of other Generation 1.5 Korean-Canadian university students (Kim, 2008).

Despite their privilege and perceived "model minority" status (Suzuki, 1994), both still faced challenges related to opportunities to use English, confidence in their English skills, and doubts about their future trajectories due to their Generation 1.5 immigrant status. Some Canadian universities still rely on length of residence as an indicator of L2 students' language proficiency based on the assumption that those who graduate from Canadian secondary schools no longer need support or assistance at the tertiary level (Fox, 2005), which was not the case for Yellina and Sheila.

This study yields insights into the complex relationship between language and identity in today's globalized, transnational, and technologically advanced world where "coolness" and belonging have varied meanings to diverse people, especially in the context of expatriate youth cultures (Shin, 2010). As Roberge (2009) notes, unlike earlier generations of immigrants, "acculturation without assimilation" (p. 11) is widely observed among today's Generation 1.5 youth. In this study, the two participants, dependent on parental decisions, were reluctant to come to Canada, so the process of Canadianization was slow. The changing demographics of Vancouver, English as a global language, technological advancements that enabled easier and more frequent access to homeland cultures, and mobility were some of the key elements that affected their attitudes, ideologies, and investments in their L1 and L2.

Accordingly, this study highlights the need to reevaluate notions of desired target-language communities and the role of L1 versus. L2 experts and gatekeepers, including those in one's own ethnolinguistic culture, in the LS processes of today's Generation 1.5 immigrant youth. Their experiences are rooted in and constrained by the complex webs of their surrounding sociocultural, historical, and political contexts and social networks. 
The results of this study present some implications for educators and policymakers, beginning with the stigma of being labeled ESL students (Séror, 2002; Toohey, 1992) or traitors to one's own ethnolinguistic peer group. Despite teachers' efforts to facilitate their students' learning, it is crucial for them to reevaluate their own assumptions, biases, and understandings visà-vis NNS students and their social and linguistic affiliations and other interests. That these immigrant students are positioned by themselves and others to choose between a Canadian or other(ed) identity is problematic. As Bannerji (2000) notes, Canada's mosaic approach to multiculturalism has often led to superficial celebrations of "ethnic" traditions that have essentially dichotomized Canadian society into two generic cultures: Canadian and other/ethnic.

This observation calls for a reexamination of how Canada's multicultural and language policies have been interpreted, internalized, and applied in educational settings by newcomers and Canadian-born citizens, and how this understanding affects the identity formations, sociolinguistic practices, and wellbeing of immigrant youth. Schools should strive to affirm and accommodate immigrant students' native cultures, including pop cultures, knowledge(s), and languages, not as attributes of cultural others, but as belonging to the overall constitution and resources of a more multicultural and multilingual Canada. In addition, parents of transnational students must understand the consequences of their own changing investments in their Canadian identities, residence, and employment for their children's sociocultural and linguistic affiliations and attainment.

Finally, immigrant students and their parents, teachers, and peer groups must recognize the social, emotional, academic, and economic consequences of shunning English-mediated socialization and instead aim to nurture bilingual/multilingual identities, communities, and practices in more meaningful and sustained ways, thereby enabling Generation 1.5 students to move seamlessly across languages, communities, and borders through purposeful integration in society.

\section{The Authors}

Jean Kim $(\mathrm{PhD})$ is a visiting professor in the Department of English Language and Literature at the Catholic University of Korea. Her teaching and research interests include language socialization, language and identity, sociolinguistics, and ethnic minority cultures in multicultural societies.

Patricia (Patsy) Duff is an applied linguist and professor of language and literacy education in the University of British Columbia. Her recent publications deal with language socialization across a wide range of contexts, qualitative research methods, and teaching and learning English and Chinese as international languages. 


\section{References}

Bannerii, H. (2000). The dark side of the nation: Essays on multiculturalism, nationalism and gender. Toronto, ON: Canadian Scholars' Press.

Baquedano-Lopez, P., \& Kattan, S. (2008). Language socialization in schools. In P. Duff \& N. Hornberger (Eds.), Encyclopedia of language and education, volume 8: Language socialization (2nd ed., pp. 161-173). New York: Springer.

Bhabha, H. (1990). Interview with Homi Bhabha: The third space. In J. Rutherford (Ed.), Identity: Community, culture, difference (pp. 207-221). London: Lawrence \& Wishart.

Block, D. (2007). Second language identities. London: Continuum.

Blumenthal, A. (2002). English as a second language at the community college: An exploration of context and concerns. New Directions for Community Colleges, 117, 45-54.

Bourdieu, P. (1977). The economics of linguistic exchanges. Social Science Information, 16, 645668.

Cervatiuc, A. (2009). Identity, good language learning, and adult immigrants in Canada. Journal of Language, Identity, and Education, 8, 254-271.

Cheng, L. \& Fox, J. (2008). Towards a better understanding of academic acculturation: Second language students in Canadian universities. Canadian Modern Language Review, 65, 307333.

Chiang-Hom, C. (2004). Transnational cultural practices of Chinese immigrant youth and parachute kids. In J. Lee \& M. Zhou (Eds.), Asian American youth: Culture, identity, and ethnicity (pp.143-158). New York: Routledge.

Crisostomo, M., \& Dee, J. R. (2001, November). Immigrants in US Colleges: What contributes to their academic success. Paper presented at the Annual Meeting of the Association for the Study of Higher Education, Richmond, VA.

Cummins, J. (1996). Negotiating identities: Education for empowerment in a diverse society. Ontario, CA: California Association for Bilingual Education.

Danico, M.Y. (2004). The 1.5 generation: Becoming Korean American in Hawaii. Honolulu, HI: University of Hawaii Press.

Duff, P.A. (2001). Learning English for academic and occupational purposes. TESOL Quarterly, 35, 606-607.

Duff, P.A. (2002). The discursive co-construction of knowledge, identity, and difference: An ethnography of communication in the high school mainstream. Applied Linguistics, 23, 289322.

Duff, P.A. (2003). New directions in second language socialization research. Korean Journal of English Language and Linguistics, 3, 309-339.

Duff, P.A. (2004). Intertextuality and hybrid discourses: The infusion of pop culture in educational discourse. Linguistics and Education, 14, 231-276.

Duff, P.A. (2007). Second language socialization as sociocultural theory: Insights and issues. Language Teaching, 40, 309-319.

Duff, P.A. (2008a). Language socialization, higher education, and work. In P. Duff \& N. Hornberger (Eds.), Encyclopedia of language and education, volume 8: Language socialization (2nd ed., pp. 257-270). New York: Springer.

Duff, P.A. (2008b). Case study research in applied linguistics. Mahwah, NJ: Erlbaum.

Duff, P.A. (2010a). Language socialization. In S. McKay \& N. H. Hornberger (Eds.), Sociolinguistics and language education (pp. 427-452). Bristol, UK: Multilingual Matters.

Duff, P.A. (2010b). Language socialization into academic discourse communities. Annual Review of Applied Linguistics, 30, 169-192.

Duff, P.A. (2011). Second language socialization. In A. Duranti, E. Ochs, \& B. Schieffelin (Eds.), Handbook of language socialization (pp. 564-586). Malden, MA: Wiley- Blackwell.

Duff, P.A., \& Hornberger, N. (Eds.). (2008). Encyclopedia of language and education, volume 8: Language socialization (2nd ed.). New York: Springer. 
Duff, P.A., \& Kobayashi, M. (2010). The intersection of social, cognitive, and cultural processes in language learning: A second language socialization approach. In R. Batstone (Ed.), Sociocognitive perspectives on language use and language learning (pp. 75-93). Oxford, UK: Oxford University Press.

Duff, P.A., \& Talmy, S. (2011). Language socialization approaches to second language acquisition: Social, cultural, and linguistic development in additional languages. In D. Atkinson (Ed.), Alternative approaches to second language acquisition (pp. 95-116). New York: Routledge.

Duranti, A., Ochs, E., \& Schieffelin, B. (Eds.). (2011). Handbook of language socialization. Malden, MA: Wiley-Blackwell.

Fix, M., \& Passel, J. (2003). U.S. immigration: Trends and implications for schools. Washington, DC: Urban Institute.

Fox, J. (2005). Rethinking second language admission requirements: Problems with languageresidency criteria and the need for language assessment and support. Language Assessment Quarterly, 2, 85-115.

Garrett, P. B., \& Baquedano-Lopez, P. (2002). Language socialization: Reproduction and continuity, transformation and change. Annual Review of Anthropology, 31, 339-361.

Guardado, M. (2009). Speaking Spanish like a boy scout: Language socialization, resistance, and reproduction in a heritage language scout troop. Canadian Modern Language Review, $66,101-129$.

Gunderson, L. (2000). Voices of the teenage diasporas. Journal of Adolescent and Adult Literacy, 43, 692-706.

Gunderson, L. (2007). English-only instruction and immigrant students in secondary schools: A critical exmaination. Mahwah, NJ: Erlbaum.

Harklau, L. (2000). From the "good kids" to the "worst": Representations of English language learners across educational settings. TESOL Quarterly, 34, 35-67.

Harklau, L. (2003). Representational practices and multi-modal communication in U.S. high schools: Implications for adolescent immigrants. In R. Bayley \& S.R. Schecter (Eds.), Language socialization in bilingual and multilingual societies (pp. 83-97). Clevedon, UK: Multilingual Matters.

Harklau, L., Losey, K., \& Siegal, M. (Eds.). (1999). Generation 1.5 meets college composition: Issues in the teaching of writing to U.S.-educated learners of ESL. Mahwah, NJ: Erlbaum.

Heath, S.B. (1983). Ways with words: Language, life, and work in communities and classrooms. Cambridge, UK: Cambridge University Press.

Hurh, W.M. (1993). The 1.5 generation: A paragon of Korean-American pluralism. Korean Culture, 14, 17-27.

Hurh, W.M. (1998). The Korean Americans. Westport, CT: Greenwood Press.

Jeon, M. (2001). Avoiding FOBs: An account of a journey. Working Papers in Educational Linguistics, 17(1-2), 83-106.

Jo, H.Y. (2002). Negotiating ethnic identity in the college Korean language classes. Identities: Global Studies in Culture and Power, 9(1), 87-115.

Kanno, Y., \& Varghese, M.M. (2010). Immigrant and refugee ESL students' challenges to accessing four-year college education: From language policy to educational policy. Journal of Language, Identity, and Education, 9, 310-328.

Kibria, N. (2000). Race, ethnic options, and ethnic binds: Identity negotiation of second generation Chinese and Korean Americans. Sociological Perspectives, 43(1), 77-95.

Kim, J. (2008). Negotiating multiple investments in languages and identities: The language socialization of Generation 1.5 Korean-Canadian university students. Unpublished doctoral dissertation, University of British Columbia.

Kramsch, C. (1998). Language and culture. Oxford, UK: Oxford University Press.

Lave, J., \& Wenger, E. (1991). Situated learning: Legitimate peripheral participation. Cambridge, UK: University of Cambridge Press. 
Leki, I. (1999). "Pretty much I screwed up": Ill-served needs of a permanent resident. In L. Harklau, K. Losey, \& M. Siegal (Eds.), Generation 1.5 meets college composition: Issues in the teaching of writing to U.S.-educated learners of ESL (pp. 17-43). Mahwah, NJ: Erlbaum.

$\mathrm{Li}, \mathrm{D}$. (2000). The pragmatics of making requests in the L2 workplace: A case study of language socialization. Canadian Modern Language Review, 57, 58-87.

Lien, P., Conway, M.M., \& Wong, J. (2003). The contours and sources of ethnic identity choices among Asian Americans. Social Science Quarterly, 84, 461-481.

Marshall, C., \& Rossman, G.B. (1989). Designing qualitative research. Newbury Park, CA: Sage.

McKay, S., \& Wong, S. (1996). Multiple discourses, multiple identities: Investment and agency in second-language learning among Chinese adolescent immigrant students. Harvard Educational Review, 66, 577-608.

Miele, C. (2003). Bergen Community College meets Generation 1.5. Community College Journal of Research and Practice, 27, 603-612.

Moon, Y.S. (2003). Canada imine kwanhan y n'gu: Hy nhwangkwa ch nmang [Research on immigration to Canada: The current situation and future predictions]. Canada Nonch'ong, 9, 89-104.

Morita, N. (2000). Discourse socialization through oral classroom activities in a TESL graduate program. TESOL Quarterly, 34, 279-310.

Morita, N. (2004). Negotiating participation and identity in second language academic communities. TESOL Quarterly, 38, 573-603.

Morita, N., \& Kobayashi, M. (2008). Academic discourse socialization in a second language. In P. Duff \& N. Hornberger (Eds.), Encyclopedia of language and education, volume 8: Language socialization (2nd ed., pp. 243-255). New York: Springer.

Norton, B. (2000). Identity and language learning: Gender, ethnicity and educational change. Essex, UK: Pearson Education.

Ochs, E. (1988). Culture and language development: Language acquisition and language socialization in a Samoan village. Cambridge, UK: Cambridge University Press.

Ochs, E., \& Schieffelin, B. (2008). Language socialization: An historical overview. In P.A. Duff and N.H. Hornberger (Eds.), Encyclopedia of language education (2nd ed.), Vol. 8, Language Socialization (pp. 3-15). New York: Springer.

Oudenhoven, E.D. (2006). Caught in the middle: Generation 1.5 Latino students and English language learning at a community college. Unpublished doctoral dissertation, Loyola University, Chicago, IL.

Palmer, J.D. (2007). Who is the authentic Korean American? Korean-born Korean American high school students' negotiations of ascribed and achieved identities. Journal of Language, Identity, and Education, 6, 277-298.

Park, E.K. (2001, April). Imin y lp'ung, wae Canada in'ga? [The immigration wave, why Canada?]. Shindonga, 420-432.

Park, G.C. (2001, April). Multiple dimensions of ethnic persons: Listening to Korean-American college students. Paper presented at the annual meeting of the American Educational Research Association, Seattle, WA.

Park, J.S.-Y. (2009). The local construction of a global language: Ideologies of English in South Korea. New York: Mouton de Gruyter.

Park, K. (1999). "I really do feel I'm 1.5": The construction of self and community by young Korean Americans. Amerasia Journal, 25(1), 139-163.

Pon, G., Goldstein, T., \& Schecter, S.R. (2003). Interrupted by silences: The contemporary education of Hong Kong-born Chinese Canadians. In R. Bayley \& S.R. Schecter (Eds.), Language socialization in bilingual and multilingual societies (pp. 114-127). Clevedon, UK: Multilingual Matters.

Roberge, M. (2001). Institutional responses to immigrant college students: An ethnographic case study of a college composition, basic writing and English as a second language program. Unpublished doctoral dissertation, University of California, Berkeley. 
Roberge, M. (2002). California's Generation 1.5 immigrants: What experiences, characteristics, and needs do they bring to our English classes? CATESOL Journal, 14(1), 107-129.

Roberge, M. (2009). A teacher's perspective on generation 1.5. In M. Roberge, L. Harklau, \& M. Siegal (Eds.), Generation 1.5 in college composition: Teaching ESL to U.S.-educated learners of ESL (pp. 3-24). New York: Routledge.

Roberge, M., Harklau, L., \& Siegal, M. (Eds.). (2009). Generation 1.5 in college composition: Teaching ESL to U.S.-educated learners of ESL. New York: Routledge.

Roessingh, H., \& Kover, P. (2002). Working with younger-arriving ESL learners in high school English: Never too late to reclaim potential. TESL Canada Journal, 19, 1-20.

Rumbaut, R., \& Ima, K. (1988). The adaptation of Southeast Asian refugee youth: A comparative study. Available: ERIC database ED299372.

Ryu, C. (1991). 1.5 Generation. In J.F.J. Lee (Ed.), Asian American experiences in the United States: Oral histories of first to fourth generation of Americans from China, Philippines, Japan, India, the Pacific Islands, Vietnam and Cambodia (pp. 50-54). Jefferson, NC: McFarland \& Company.

Salzberg, J.L. (1998). Taiwanese immigrant parents' perceptions of their adolescent children's ESL learning and academic achievement. Unpublished master's thesis, University of British Columbia.

Schecter, S.R., \& Bayley, R. (2002). Language as cultural practice: Mexicanos en el norte. Mahwah, NJ: Erlbaum.

Schieffelin, B. (1990). The give and take of everyday life: Language socialization of Kaluli children. New York: Cambridge University Press.

Schwartz, G.G. (2004). Coming to terms: Generation 1.5 students in mainstream composition. The Reading Matrix, 4(3), 40-57.

Séror, J. (2002). Learning from example: Exploring immigrant language minority students' perceptions of what it takes to "make it" as an ESL student. Unpublished master's thesis, University of British Columbia.

Séror, J. (2008). Socialization in the margins: Second language writers and feedback practices in university content courses. Unpublished doctoral dissertation, University of British Columbia.

Shin, H. (2010). "Gireogi gajok": Transnationalism and language learning. Unpublished doctoral dissertation, OISE/University of Toronto.

Singhal, M. (2004). Academic writing and generation 1.5: Pedagogical goals and instructional issues in the college composition classroom. The Reading Matrix, 4(3), 1-13.

Statistics Canada. (2008). Profile of language, immigration, citizenship, mobility and migration, 2006 Census. Available:

http://www5.statcan.gc.ca/bsolc/olc-cel/olc-cel?catno=94-577-X\&chropg=1\&lang=eng

Stegemoller, J. (2004). A comparison of an international student and an immigrant student: Experiences with second language writing. The Reading Matrix, 4(3), 58-85.

Suzuki, B. (1994). Higher education issues in the Asian American community. In M. Justiz, R. Wilson, \& L. Bjork (Eds.), Minorities in higher education (pp. 258-285). Phoenix, AZ: Oryx Press.

Talmy, S. (2005). Lifers and FOBs, rocks and resistance: Generation 1.5, identity, and the cultural productions of ESL in a high school. Unpublished doctoral dissertation, University of Hawai'i at Manoa.

Talmy, S. (2008). The cultural productions of the ESL student at Tradewinds High: Contingency, multidirectionality, and identity in L2 socialization. Applied Linguistics, 29, 619-644.

Talmy, S. (2010). Qualitative interviews in applied linguistics: From research instrument to social practice. Annual Review of Applied Linguistics, 30, 128-148.

Toohey, K. (1992). We teach English as a second language to bilingual students. In B. Burnaby \& A. Cumming (Eds.), Sociopolitical aspects of ESL in Canada (pp. 87-96). Toronto, ON: OISE Press. 
Toohey, K. (2005). Assigning marginality: The case of an "ESL/learning disabled" student. Research on Immigration and Integration in the Metropolis Working Paper Series (No. 05-04). Available: http:/ / riim.metropolis.net/assets/uploads/files/wp/2005/WP05-04.pdf

Toohey, K., \& Derwing, T. M. (2006). Hidden losses: How demographics can encourage incorrect assumptions about ESL high school students' success. Research on Immigration and Integration in the Metropolis. Working Paper Series (No. 06-11). Vancouver, BC: Vancouver Centre of Excellence.

Toohey, K., \& Gajdamaschko, N. (2005). Communities of practice, figured worlds and learning initiatives in the second language education of immigrant students. Research on Immigration and Integration in the Metropolis Working Paper Series (No. 05-03). Available: http://riim.metropolis.net/assets/uploads/files/wp/2005/WP05-03.pdf

Watson-Gegeo, K.A. (1992). Thick explanation in the ethnographic study of child socialization: A longitudinal study of the problem of schooling for Kwara'ae (Solomon Islands) children. In W.A. Corsaro \& P.J. Miller (Eds.), Interpretive approaches to children's socialization: New directions for child development (pp. 51-66). San Francisco, CA: Jossey-Bass.

Watt, D., \& Roessingh, H. (2001). The dynamics of ESL drop-out: Plus ça change ... Canadian Modern Language Review, 58, 203-222.

Yi, Y. (2009). Adolescent literacy and identity construction among 1.5 generation students: From a transnational perspective. Journal of Asian Pacific Communication, 19(1), 100-129.

Yim, Y.K. (2011). Second language students' discourse socialization in academic online communities. Canadian Modern Language Review, 67, 1-27.

Yoon, Y.J. (2001). Ch'aegun imin tonghyang kwa p'y ngga [The assessment of recent emigration traits]. Wae Gyo (Foreign Relations), 57, 115-127.

Yoon, I.J., Lim, C.K., \& Bae, Y.J. (2007). The current state and socioeconomic status attainment of Korean-Canadians: Inter-generation and inter-group comparisons. Korean Review of Canadian Studies, 13, 173-193.

Zamel, V. (1995). Strangers in academia: The experiences of faculty and ESL students across the curriculum. College Composition and Communication, 46(4), 506-521.

Zappa, S. (2007). The academic literacy socialization of Mexican exchange students at a Canadian university. Unpublished doctoral dissertation, University of British Columbia.

Zappa-Hollman, S. (2007). Academic presentations across post-secondary contexts: The discourse socialization of non-native English speakers. Canadian Modern Language Review, 63, 455-485.

Zentella, A.C. (1997). Growing up bilingual. Malden, MA: Blackwell. 


\section{Appendix A: Sample Student Interview Questions}

1. Why did your family immigrate to Canada and how did you feel about it? What were your expectations about your new life in Canada? What were your expectations about learning English in Canada? What were your English learning experiences prior to moving to Canada?

2. Did you take ESL classes in secondary school in Canada? How was that experience? Did you find the ESL classes helpful? What did you study in those classes? Did you receive private tutoring in English or in other subjects in secondary school?

3. Who were your closest group of friends in secondary school? What language(s) did you use with these friends? Did you "hang out" with these friends after school? If so, what kind of activities did you and your friends take part in?

4. What was your favorite subject in high school? Which subject(s) did you excel in and which subject(s) did you find challenging? What aspects about these subjects were challenging for you? How was your experience in regular English classes in secondary school?

5. What were your expectations socially and academically of university life prior to attending [PCU]? Were these expectations met?

6. Why did you choose your major at [PCU]? What kind of courses have you taken related to your major? Have you experienced any difficulties in these courses? If so, what were they? What kinds of assignments were required in these courses (e.g., essays, research papers, group presentations, lab reports)?

7. What other courses have you taken at [PCU] that are not directly related to your major? What were your reasons for taking these courses (e.g., friends'/sŏnbaes' suggestions, schedule, personal interest)? What kinds of assignments were required in these courses? Was class participation included in the assessment criteria of these courses? If so, how was your own class participation?

8. How was your experience in first-year English courses? Which courses did you take? What kinds of assignments were required in your classes? Have you ever asked for help from your instructors or TAs? Have you ever been to [PCU]'s writing centre to get help on your assignments? Do you ever ask other people (peers, siblings) to look over your written assignments?

9. Who are your closest group of friends at [PCU]? What language(s) do you use with these friends? Are you involved in any extracurricular activities both in and outside [PCU]? If so, what were your reasons for participating in them (e.g., friends' encouragement, needed for future job application) Do you socialize with friends outside of [PCU]? If so, in what context, and what language(s) do you use with them?

10. Do you keep in touch with your friends from Korea (e.g., through e-mail, Web Messenger, phone, personal blogs)? Have you ever visited Korea after moving to Canada? If so, what was that experience like? If not, do you plan to visit in the near future?

11. What are your future professional aspirations? Do you have plans to work outside Canada? If so, why? If any, what are some of the challenges you might face in achieving your future professional goal? What role does English play in your future profession?

12. If someone asked you "where are you from," how would you answer this question? 
13. Are you involved in any Korean organizations or communities in Vancouver? If so, what are your reasons for taking part in them? What language(s) do you use when you take part in those activities?

14. What kind of advice would you give to newly arrived Korean immigrant students in Vancouver? This can be related to their studies, learning English, making friends, and so on.

15. Are you familiar with the term Generation 1.5? If so, would you consider yourself a Generation 1.5 immigrant? What is your understanding of this generation? If someone asked you what/who 'Generation 1.5' is, how would you answer this question? 